\title{
FACTORS AFFECTING THE SUCROSE CONTENT OF SUGARCANE: FERTILIZERS
}

\author{
G. Samuels, M. A. Lugo López and P. Landrau Jr. ${ }^{1}$
}

\section{INTRODUCTION}

In the fertilization of sugarcane, both tonnage and sucrose concentrations are important and must be given due consideration. The effect of increasing of cane tonnage by the use of fertilizers can be nullified if this increased yield is accompanied by a decrease in sucrose concentrations. On the other hand, no increase in yields of cane per acre would be entirely acceptable if the fertilizer decreased sucrose concentrations significantly.

As a quantitative illustration of the intimate relationship between cane tonnage and sucrose concentrations, the following example may prove of value.

A field produces 40 tons of millable cane per acre with a mean sucrose concentration of 12 percent. This gives 96 hundredweights of sugar. If by the use of fertilizers we were to increase the sucrose content of the cane but 1 percent, from 12 to 13, the yield of sugar would be 104 hundredweights per acre. To obtain the same quantity of sugar per acre from the 12-percent cane, it would be necessary to obtain an increase of 3.3 tons. It is also to be remembered that increased sucrose content means more sugar per acre without increased cane tonnage which involves higher labor costs in harvesting. That is, by harvesting 40 tons of a 13-percent cane a grower obtains the same amount of sugar per acre as does the grower who harvests 43.3 tons of a 12-percent cane, with the added profit that the farmer does not have to pay the labor costs involved for harvesting the extra 3.3 tons of cane. This example emphasizes that, for proper evaluation of sugarcane fertilizers, consideration should be given not only to influence on cane tonnage but also to influence on sucrose concentration.

The literature on sugarcane fertilizers abounds in data concerning fertilizers and cane tonnage. The data related to fertilizers and sucrose concentrations are not so plentiful and are rather conflicting (5)..$^{2} \mathrm{It}$ is the purpose of this paper to present and interpret the data on the influence of fertilizer on sucrose concentrations for Puerto Rico, as determined by over 15 years of fertilizer research conducted by the Agricultural Experiment Station of the University of Puerto Rico.

${ }^{1}$ Plant Physiologist, Associate Soil Scientist, and Assistant Agronomist, respectively, Agricultural Experiment Station, University of Puerto Rico, Río Piedras, P. R.

${ }^{2}$ Numerals in parentheses refer to Literature Cited, p. 202. 


\section{Effects of Major-Element Fertilizers}

\section{NITROGEN}

In Puerto Rico, nitrogen is responsible for more increases in cane tonnage than any other fertilizer element. The data from 152 field experiments of the Agronomy Department covering the leading sugarcane varieties and producing areas were utilized in determining the influence of nitrogen on sucrose percent cane. The results are presented in figure 1, expressed in

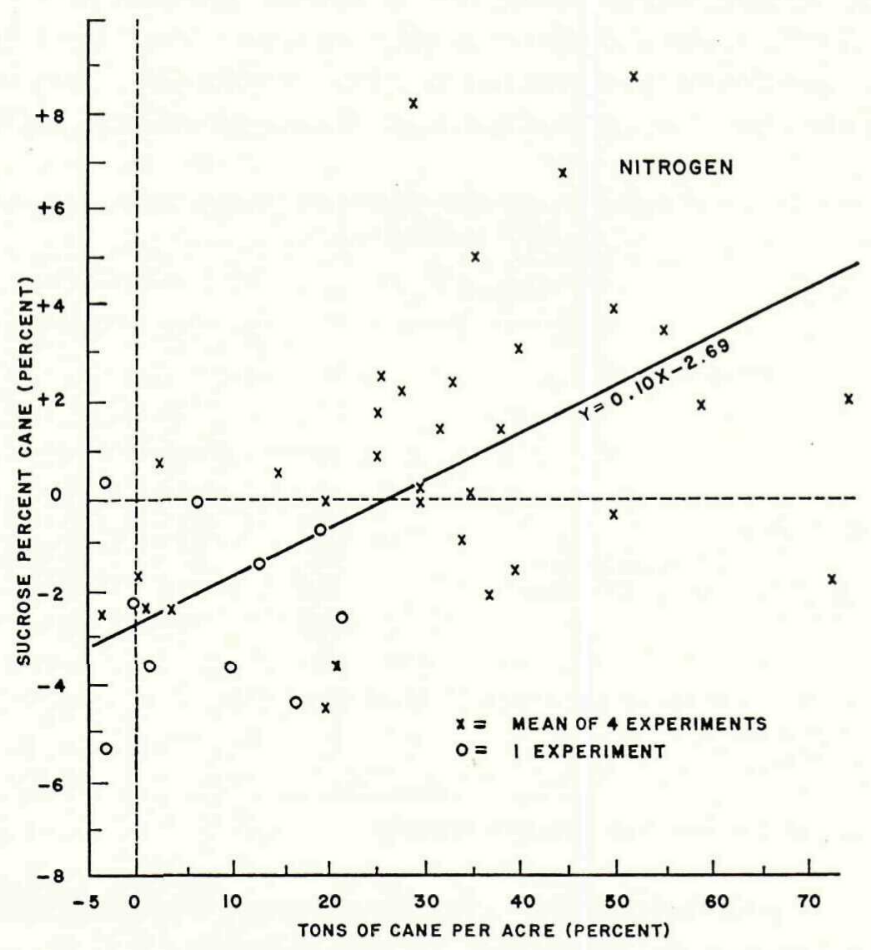

FIG. 1.-Influence of nitrogen fertilizer on the percentage increase or decrease in tons of cane per acre and in sucrose percent cane.

percentage increase in yield and in sucrose percent cane. This percentage increase represents the increase in either tons of cane or sucrose of treatments with nitrogen fertilizer when compared to the no-nitrogen treatment. The graph shows a definite linear relationship between percentage increase in tons of cane and percentage increase in sucrose percent cane. The regression equation obtained was $Y=0.10 x-2.69$ where $Y$ is the percentage increase in sucrose percent cane and $x$ is the percentage increase in tons of cane per acre. The regression of percentage increase in sucrose percent 
cane on percentage increase in tons of cane per acre was very highly significant at the 1-percent level.

It is often stated in discussing sugarcane fertilization that the use of nitrogen in large quantities lowers the sucrose content of the cane. The data presented in figure 1 do not support this belief. The findings here indicate that an increase in yield of cane per acre obtained by the use of more nitrogen is accompanied by an increase in sucrose percent cane. However, as revealed by the equation $Y=0.10 x-2.69$, an increase in sucrose percent cane is only realized after the percentage increase in tons of cane reaches 27 . Thus, small increases in cane tonnage are not accompanied by appreciable increases in sucrose content, but by decreases. The use of nitrogen on cane which has no need for it, or of large quantities of nitrogen for

TABLE 1.-Influence of different nitrogen sources on sucrose percent cane for P.O.J. $28 \% 8$ at Rio Piedras

\begin{tabular}{|c|c|c|c|c|}
\hline \multicolumn{4}{|l|}{ Treatment } & \multirow{3}{*}{$\begin{array}{c}\text { Sucrose } \\
\text { percent cane }\end{array}$} \\
\hline \multirow{2}{*}{ Nitrogen carrier } & \multicolumn{3}{|c|}{ Fertilizer per acre } & \\
\hline & $\mathrm{N}$ & $\mathrm{P}_{2} \mathrm{O}_{5}$ & $\mathrm{~K}_{2} \mathrm{O}$ & \\
\hline . & Pounds & Pounds & Pounds & Percent \\
\hline None............... & 0 & 50 & 50 & 12.18 \\
\hline Ammonium sulfate............... & 206 & 50 & 50 & 12.20 \\
\hline Ammonium nitrate, 1 application. .... & 206 & 50 & 50 & 12.18 \\
\hline Ammonium nitrate, 2 applications ....... & 206 & 50 & 50 & 12.07 \\
\hline 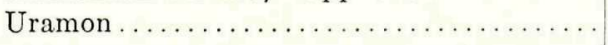 & 206 & 50 & 50 & 12.33 \\
\hline \multirow{2}{*}{\multicolumn{4}{|c|}{ 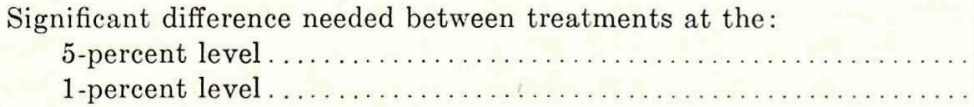 }} & \\
\hline & & & & $\begin{array}{r}0.57 \\
.75\end{array}$ \\
\hline
\end{tabular}

1 Average of a plant cane and two ratoons.

cane which needs but moderate fertilization, will produce little increase in tons of cane, and the sucrose content will either not be affected or slightly decreased. When nitrogen was used on cane which responded by an increased yield of over 27 percent, there were increases in the sucrose content of the cane.

The source of nitrogen used for sugarcane had no influence on the sucrose content of the cane in experiments conducted at Río Piedras. In table 1, the data show no significant difference regardless of nitrogen sources or the manner of application. Data given in a previous publication (8) also revealed no significant influence on yield of cane attributable to nitrogen source. Similar work in Hawaii (1) failed to reveal any difference in the sucrose yields of canes fertilized with various nitrogen carriers, namely, 
nitrate of soda, ammonium sulfate, potassium nitrate, calcium nitrate, urea, Calurea, Uramon, and ammonium nitrate.

Clements (2) states that the addition of large quantities of nitrogen means an accompanying need of the sugarcane plant for more carbohydrates, and as a result, comparatively small quantities are stored by the plant. By applying a heavy dose of nitrogen, Clements believes the storage capacity of the cane is increased, but less is left to be stored. However, for the conditions of the experiments reported in this paper, increasing the cane tonnage was accompanied by an increase in sucrose. The maximum nitrogen used was 250 pounds per acre. It is, of course, plausible to expect a decrease in both tonnage and sucrose with too heavy applications of nitrogen. For Puerto Rico, it appears that the use of up to 250 pounds of nitrogen per acre for cane is not harmful either to sucrose percent cane or tonnage.

\section{PHOSPHORUS}

The results of 144 field experiments showed no significant response in the sucrose content of cane from phosphorus fertilizers. The data shown in figure 2 reveal no definite trend in sucrose response to the use of phosphorus. In general, there is a very little difference in yield of cane attributable to phosphorus, the response on the average being less than a 10percent increase. The majority of the increases in sucrose percent cane lie within a -6 to +3 range. The graph indicates that no decreases in tons of cane were accompanied by decreases in sucrose content. Where large increases in tons of cane were encountered (over 10 percent), the response in sucrose percent cane was sometimes negative and sometimes positive.

Martin (6) and Saito and Kenjo (7) reported a reduction in the sucrose content of cane grown in nutrient solutions. However, these reductions were not observed in field work $(3,9)$. The phosphorus needed for sugarcane to perform its normal physiological role in sucrose formation and accumulation seemed to be adequately supplied by the sugarcane soils of Puerto Rico.

\section{POTASSIUM}

The data from 144 field experiments revealed no significant difference in sucrose concentration attributable to potassium fertilizers. In general, the response in yield from potash applications was low. The majority of the increases in tons of cane per acre were less than 10 percent, and the maximum was 18. (See figure 3). The increases in sucrose concentration were generally accompanied by yield increases. These increases in sucrose were not consistent, and figure 3 shows increases in sucrose concentration varying from -8 to +8 percent all within a range of a 2 - to 10 -percent increase in tons of cane. 
Although, the majority of the sucrose increases were positive (72 percent), there was no significant relationship between the application of potash and sucrose concentrations. The reason may be that only small yield responses are obtained from potash fertilizers in Puerto Rico. The evidence in the literature on the influence of potash on sucrose content is controversial. A careful examination reveals that potassium is essential for high sucrose values, and that its complete omission leads to low sucrose con-

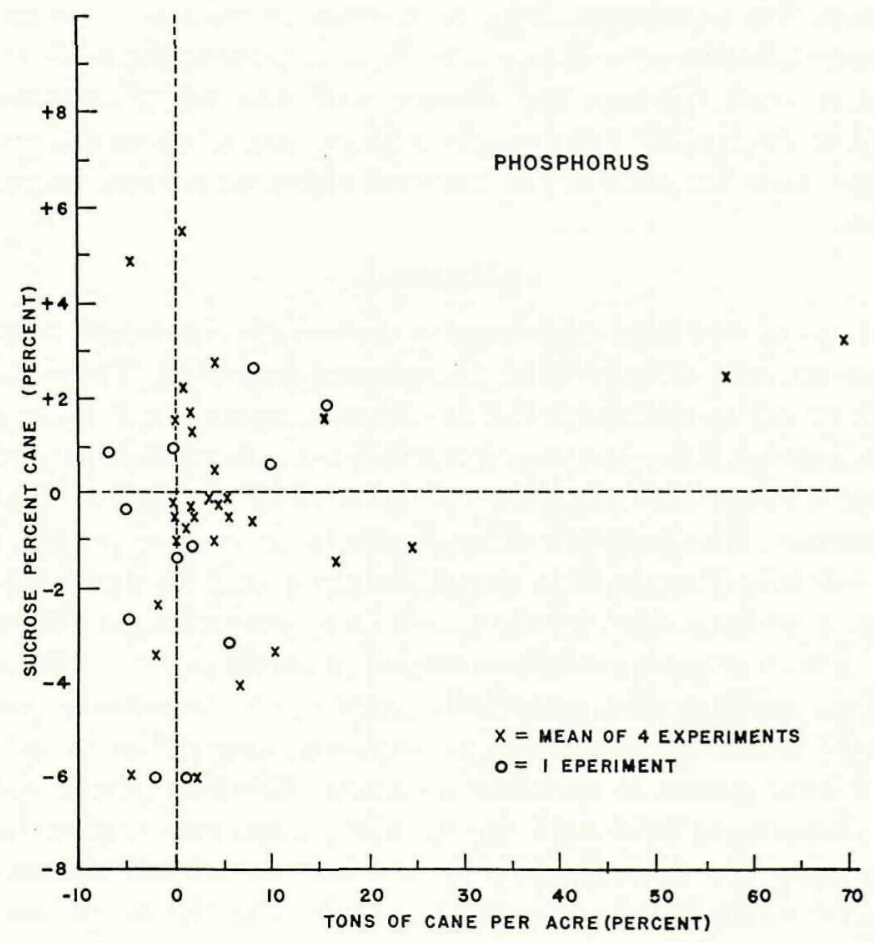

FIG. 2.-Influence of phosphorus fertilizer on the percentage increase or decrease in tons of cane per acre and in sucrose percent cane.

centrations. However, the soils of Puerto Rico seem to contain sufficient potash to ensure good sucrose concentrations. The application of potash then, does not necessarily produce an increase in the sucrose content of the cane. Innes (4) in Jamaica obtained significant increases in the sucrose percent cane only when yield responses were 20 percent or greater. It must be remembered that the highest yield increase found in figure 3 was 18 percent. If further responses in yield are possible, it may be that increases in sucrose concentrations will follow. 


\section{Effects of Minor-Element Fertilizers}

The use of minor-element fertilizers on sugarcane has produced no general significant increases in the sucrose content of cane in Puerto Rico. This is also true for cane tonnage. The response of sugarcane as increases in tons of cane and sucrose percent cane from the use of minor element fertilizers is shown in figure 4. The tonnage increase is almost always lower than 7 percent. The sucrose results are sometimes negative and sometimes positive.

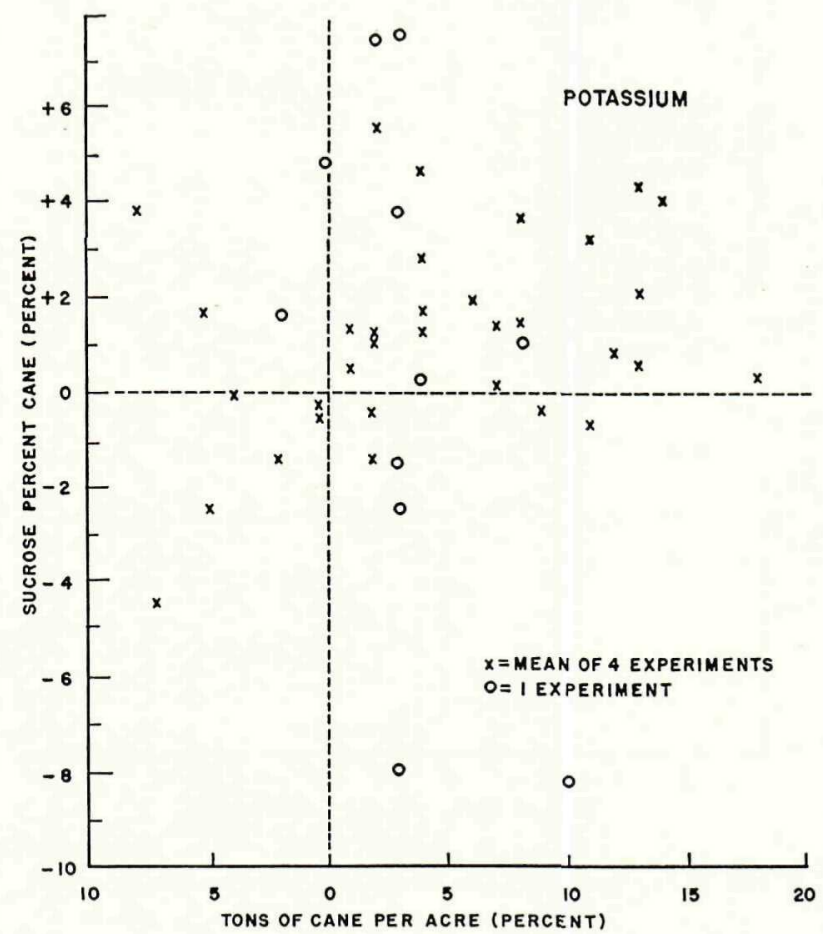

FIG. 3.-Influence of potassium fertilizer on the percentage increase or decrease in tons of cane per acre and in sucrose percent cane.

Magnesium produced 4 negative responses and also 3 positive responses in sucrose percent cane. Copper gave increases in sucrose for all 4 experiments in which it was used; the increases ranged from 1.3 to 7.2 percent. However, the yield decreases or increases in cane ranged from -14.4 to +10.8 percent.

Zinc and manganese produced both negative and positive responses in sucrose concentration. Boron showed 4 positive responses and 1 negative response in the 5 experiments in which it was used. The application of 
sodium did not produce any definite positive response in sucrose content. Iron and sulfur produced increases in sucrose content. Results with calcium were both positive and negative from the standpoint of increases in sucrose. The soils where the lime was used, however, all had a $\mathrm{pH}$ above 6.2.

There is no evidence in the literature of any appreciable increases in sucrose content of sugarcane with the use of minor-element fertilizers. Nutrient-culture work, in which a minor element was entirely omitted from the medium, provided some evidence of the need of certain minor elements for normal sucrose production. Most soils, however, have sufficient supplies

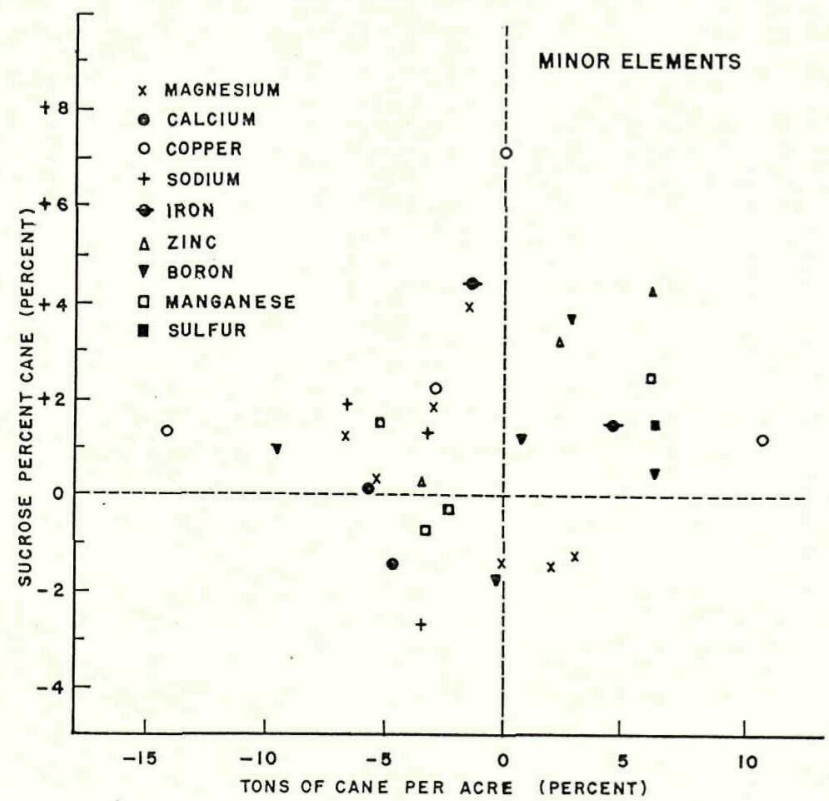

FIG. 4.-Influence of certain minor-element fertilizers on the percentage increase or decrease in tons of cane per acre and in sucrose percent cane.

of the needed minor elements, and no appreciable responses are obtained in yield or sucrose content.

\section{Summary}

The results of over 150 field experiments with sugarcane conducted by the Agricultural Experiment Station of the University of Puerto Rico covering a wide range of varieties and soils of Puerto Rico revealed the following:

1. Nitrogen produced an increase in sucrose content with increased cane yields. When the percentage increase in cane tonnage is plotted against 
the percentage increase in sucrose percent cane, a highly significant regression is obtained. The equation obtained reveals that a significant increase in sucrose concentration occurs only after increases in yields are over 27 percent.

2. Different nitrogen sources, namely, ammonium nitrate, ammonium sulfate, and Uramon, produced no significant differences in influence on sucrose concentrations.

3. The application of phosphorus had no significant effect on the sucrose content of sugarcane. Cane tonnage responses were also slight.

4. The use of potassium fertilizers did not significantly influence the sucrose content of sugarcane. Where there was an increase in yield, there was generally an increase in sucrose content. Percentage increases in yield of cane, however, were very low, the majority being less than 10 percent. The soils seem to contain sufficient potassium for good sucrose concentrations, and the use of potash as fertilizer does not usually produce any significant increases in sucrose.

5. The minor-element fertilizers produced no significant increases in sucrose content. The use of copper, magnesium, zinc, boron, manganese, calcium, sodium, iron, and sulfur produced no appreciable increases in yield. The majority of percentage yield increases were less than 7 , while percentage decreases or increases in sucrose content varied from -3 to +7 .

\section{RESUMen}

Los resultados de más de 150 experimentos de campo con distintas variedades de caña azúcar, llevados a cabo por la Estación Experimental Agrícola de la Universidad, en distintos suelos de Puerto Rico señalan lo siguiente:

1. La aplicación de nitrógeno produjo un aumento en el contenido de sacarosa y en los rendimientos. Cuando se calculó el porcentaje de aumento en el tonelaje producido comparándolo con el porcentaje de aumento del por ciento de sacarosa se obtuvo una regresión altamente significativa. En este caso, la ecuación revela que el aumento significativo en la concentración de sacarosa se obtuvo sólo cuando los aumentos en los rendimientos fueron sobre el 27 por ciento.

2. Las diferentes fuentes de nitrógeno, a saber, nitrato de amonio, sulfato de amonio, y Uramón no tuvieron influencia significativa sobre las concentraciones de sacarosa.

3. La aplicación de fósforo no ejerció efecto significativo alguno sobre el contenido de sacarosa en la caña, como también fué insignificante su influencia sobre los rendimientos.

4. La aplicación de potasio no tuvo efecto significativo alguno sobre el 
contenido de sacarosa en la caña. Cuando se registró un aumento de la sacarosa, generalmente hubo un aumento en el contenido de sacarosa. Los porcentajes de aumento en los rendimientos fueron, sin embargo, muy bajos, en su mayoría menos del 10 por ciento.

Tal parece que los suelos contienen suficiente potasio para proveer una buena concentración de sacarosa, por lo que la presencia de este elemento en los abonos no aumenta de por sí el contenido de sacarosa en la caña.

5. La aplicación de los elementos menores conjuntamente con los abonos no surte efecto significativo alguno en el contenido de sacarosa. Los siguientes elementos menores, magnesio, zinc, boro, manganeso, calcio, sodio, hierro y azufre no produjeron aumentos apreciables en los rendimientos. El porcentaje de aumento en los rendimientos fué en su mayoría menor del 7 , mientras que el de los cambios en el contenido de sacarosa varió de $-3 \mathrm{a}+7$.

\section{Literature Cited}

1. Borden, R. A., Recent developments in sources of nitrogen for fertilizing crops, Hawaiian Planters' Rec., 53 79-88, 1949.

2. Clements, H. F., Integration of physiologic and climatic factors with reference to production of sugarcane, Hawaiian Planters' Rec., 44 201-233, 1940.

3. Denison, F. C., Report of Committee in Charge of the Experiment Station, Hawaiian Sugar Planters' Association, p. 97, 1927.

4. Innes, R. F. and Chinley, T., The Effects of Fertilizers on Sugarcane; I. Potash, Paper of the Sugar Research Dept. of Sugar Manufacturers' Assoc. of Jamaica, Ltd., 1951.

5. Lugo López, M. A. and Capó, B. G., Factors Affecting the Sucrose Content of Sugarcane, $I$-Historical (unpublished).

6. Martin, J. P., Varietal differences of sugarcane in growth, yield, and tolerance to nutrient deficiencies, Hawaiian Planters' Rec., 45 79-91, 1941.

7. Saito, T. and Kenjo, M., On the influence of the phosphorus deficiency upon the vegetative growth, accumulation of sugar, nitrogen content, and the ash constituents in sugarcane plant, Reports of Committee on Abstract of Papers, 6th Congress. Int. Soc. of Sugarcane Technologists, p. 73-74, 1938.

8. Samuels, G., Landrau, Jr., P., and Capó, B. G., The response of sugarcane in Puerto Rico to various nitrogen sources, Jour. Agr. Univ. P. R., 35 2, April 1951.

9. Verret, J. A., Report of committee in charge of the Experiment Station, Hawaiian Sugar Planters' Assoc., p. 45, 1928. 